\title{
Is Japan Religious?
}

Christopher M. Kavanagh ${ }^{12}$ and Jonathan Jong ${ }^{13}$

1. Institute of Cognitive and Evolutionary Anthropology, University of Oxford.

2. Department of Psychology, Rikkyo University

3. Centre for Psychology, Behavior and Achievement, Coventry University.

\section{Author Note}

Christopher M. Kavanagh iD https://orcid.org/0000-0001-7545-8137

We have no known conflict of interest.

Correspondence concerning this article should be addressed to: Christopher Kavanagh, Institute of Cognitive \& Evolutionary Anthropology, University of Oxford, Oxford, UK, OX2 6PN.

Email: christopher.kavanagh@anthro.ox.ac.uk 


\begin{abstract}
The popular image of Japan and religion presents something of a paradox. On the one hand, large cross-cultural surveys frequently present Japan as a country of non-believers, where only 10-15\% of the population self-identify as religious and the vast majority rank religion as being of little importance to their lives. Yet, any visitor to Japan is likely to be struck by the sheer number of Shinto shrines and Buddhist temples that dot the landscape and the diverse array of festivals (matsuri) that are performed at these sites. In this paper, we argue that the apparent paradox is actually an illusion generated by the unwarranted ethnocentric assumption that religion everywhere must resemble the features of the Abrahamic faiths that are predominant in Western societies. To make our case we first review recurrent theoretical and definitional debates concerning religion and examine how they relate to the Japanese context. Second, we explore patterns in contemporary data from an online survey of $\mathrm{N}=1,000$ Japanese that asked about religious beliefs and practices. We illustrate through the results obtained that to understand religion in Japan it is necessary to move beyond theocentric approaches and expectations that religious belief must be tied to religious identities or exclusive membership in a given tradition. To conclude, we argue that the patterns observed in Japan demonstrate that scholars who wish to explore religion cross-culturally need to take greater account of orthopraxic cultural contexts and distinguish between 'theocentric' doctrinal beliefs and broader supernatural beliefs.
\end{abstract}

Keywords: Japanese religion; orthopraxic religion; cognitive study of religion; Japan. 


\section{Is Japan Religious?}

Japan is routinely presented as one of the least religious countries in the world (Smith 2018; Staufenberg 2016), surpassed only by China where religious activity was repressed for decades (Johnson 2017; Yang 2011). Typically this portrayal is connected to large scale cross-cultural surveys, such as the Global Index of Religiosity and Atheism (WIN-Gallup International 2012) in which only $16 \%$ of Japanese respondents self-identified as 'a religious person', while $31 \%$ identified as 'a convinced atheist'. Based on this survey WIN-Gallup ranked Japan as the second least religious country in the world. Similarly, in the 2010-2014 wave of the World Values Survey (Inglehart et al. 2014), 87\% of Japanese respondents described themselves as 'not a member' of a church or religious organization, and only $21 \%$ self-identified as 'religious', independent of attendance at religious services. Based on these and related statistics, Inglehart and Welze (2010: 554) ranked Japan highest amongst 60 countries in national secular-rational values. These patterns of low levels of religious identification have been replicated in a wide range of surveys (Institute and NHK Culture Research Institute 2008; WinGallup 2014), including recently published data (Bullivant et al. 2019). Taken collectively these results seem to offer strong support for the thesis that Japan is a non-religious country.

Yet, despite Japan's reputation for irreligiosity, recent official statistics collected by the Japanese government report the population of Japan as having 87.9 million Shinto adherents and 84.6 million Buddhists (Japan Statistics Bureau 2019). The combined total of these figures is greater than the population of Japan - 126 million in 2019-but this is not a calculation error. Rather, it illustrates that religious traditions in Japan are not perceived as exclusive and as a result many people are classified as an adherent of more than one tradition. Official statistics also record the presence of a large amount of Buddhist temples and Shinto shrines, something that even a casual visitor to Japan is likely to notice. As 
of 2019, there are a total of 216,927 registered religious organizations in Japan, including 87,967 Shinto shrines and 84,675 Buddhist temples (Japan Statistics Bureau 2019). Shrines and temples are also not simply historical relics and instead function as contemporary religious sites that provide a host of ritual services, spaces to pray, sell protective charms and amulets and host a wide variety of festivals (Covell 2005; Nelson 1996b; Reader and Tanabe 1998).

What is one to make of this seeming paradox? How is it that one of the most non-religious countries records 182 million Buddhist and Shinto adherents, over 216,000 religious sites, and hosts thousands of bustling Buddhist and Shinto festivals every year? In this paper, we grapple with this issue and argue that the paradox fades away if we recognize that 'religion' worldwide does not necessarily adhere to an Abrahamic monotheistic stereotype. We further contend that the conflicting cross-cultural survey results and official statistics are entirely compatible when understood as reflecting an 'orthopraxic' religious context (Berling 1987) in which religious beliefs need not be 'theocentric' or tied to membership in a specific religious community (Jong and Halberstadt 2016).

To present this case, first we critically review debates over what constitutes religion and consider whether under any definition, including those developed by scholars in the cognitive science of religion (CSR), this is a meaningful category to apply in a Japanese context. Second, we examine novel selfreported data on the religious beliefs and ritual practices of 1,000 Japanese respondents and argue that the results observed demonstrate the importance of disentangling affiliation, practices, and supernatural beliefs. Finally, we conclude by emphasizing the need for the adoption of a broader and less ethnocentric conception of religion that gives equivalent weight to matters of religious belief and practice and consciously avoids treating features of Abrahamic religion as a prototypical reference. Avoiding these traps enables researchers to better understand the patterns of religiosity observed in Japan and renders them coherent with patterns observed in other orthopraxic contexts. 


\section{Theoretical Review}

\section{Conflicting Definitions of Religion}

How do we make sense of the proportions of Japanese who self-identify in surveys as nonreligious and the number of Buddhist and Shinto adherents recorded in the official government statistics? A possible answer is that one of the figures is incorrect. In contrast to the figures provided from self-report surveys, official statistics are based on household affiliations and estimates of membership supplied by the various shrines and temples. Yet, the mainstream religious traditions in Japan do not require regular attendance at services and thus membership is often tied to participation at infrequent festivals or the provision of specific ritual services, such as funerals (Rowe 2011; Tsuji 2002). It is therefore likely that official estimates are artificially inflated and partially inaccurate. While this is a part of the explanation for the discrepancy, another important factor is that the cross-cultural surveys and official statistics are measuring different things. Specifically, cross-cultural surveys tend to ask respondents about their explicit religious beliefs and whether they self-identify as a religious person, whereas government statistics and the membership information kept by shrines and temples that they are in part drawn from, are concerned primarily with household affiliation. Household affiliation is typically tied to the provision of ritual services, specifically the performance of funerals (Tamamuro 1963). In short, different things are being measured under the rubric of religiosity (see also Roemer 2009).

Another issue is that the endorsement of a religious identity in Japan has broadly negative connotations amongst the general public (Inoue 2009). One reason for this is the syncretic and pluralistic nature of the Japanese religious environment. Individuals are not required to self-identify as a member of any specific religion and the norm is to participate in multiple traditions (Mullins 2011; Reader 1990). It is not unusual, nor is any contradiction perceived, in traditional homes housing both a Buddhist altar to honor deceased relatives (butsudan 仏壇) and a Shinto altar, called a god-shelf (kami-dana神棚), to 
bring blessings. Consequently, self-identification with specific religious identities tends to be regarded with some suspicion and associated with uncomfortable proselytizing (Reader 1990:199) and fanatical new religious movements ${ }^{1}$ (Inoue 2009; Metraux 1995; Reader 1996, 2000).

\section{Does it Make Sense to Talk of 'Religion' in Japan?}

As the differences in the official statistics and cross-cultural survey results illustrate how we operationalize religion and the definitions we apply matter. If religion is about household affiliation then Japan is highly religious, whereas if it is about personal endorsement of a religious identity then it may be appropriate to talk of Japan as a country of non-believers. An important question this raises is whether it is even meaningful to discuss religion in the context of Japan? After all, religion is an English term derived from a Latin root and a Western cultural context. The modern Japanese translation for religion is shūkyō, made from a combination of the characters shu (宗sect) and $k y \bar{o}$ (教teaching). The precise origins of this term remain contested; however, most scholars of Japanese history agree that the term only came into widespread popular use in the Meiji era (1868-1912) as a counterpart to the English word 'religion' (Josephson 2012; Krämer 2013, 2015; Maxey 2014).

The fact that a novel, or at least previously obscure, term was required has lead a number of critical theorists, including Fitzgerald (2003, 2004), Isomae (2003, 2012) and (Horii 2016, 2018), to argue that this demonstrates that religion was an entirely foreign concept to Japan that had to be accommodated. This is an issue as they contend that the term smuggles in a variety of unacknowledged assumptions including an emphasis on personal belief, the existence of formalized doctrines and canons, expectations of exclusive membership, and the presence of centralized religious hierarchies. Fitzgerald (2004) and Josephson (2012) note that all of these features derive from an assumed fundamental

\footnotetext{
${ }^{1}$ The infamous sarin-gas attack by the millennial cult Aum Shinrikyo on the Tokyo subway in 1995 continues to resonate in the public imagination.
} 
dichotomy between secular and religious domains, one that critical scholars argue was not present in Japan prior to contact with the Western colonial powers in the Meiji era. As Fitzgerald (2003: n.p.) explains: 'The idea that there are some special phenomena in all societies that can be described as religious or religions was not something that the people in that society decided on by themselves, but an idea received from the west'. Following this logic, academics who insist on applying the framework of 'religion' to Japan are in danger of uncritically reifying a colonial legacy and producing analyses that are 'ahistorical, atemporal and apolitical' (McCutcheon 1997:35). Consequently, critical scholars maintain that utilizing the concept of religion to examine Japanese culture is likely to be counterproductive and may obscure more than it reveals.

However, accounts positing a one-way relationship in which the Western powers unilaterally imposed their definitions of religion on passive Japanese subjects have been strongly challenged by contemporary scholarship. Recent books by Josephson (2012), Krämer (2013, 2015), and Maxey (2014) have all provided nuanced historical accounts that detail the complex negotiations and debates that Japanese people participated in when establishing the category of religion during the Meiji period. These scholars hold differing perspectives regarding how novel it was for Japanese to make distinctions between religion and secular contexts, how related premodern concepts are to later definitions, and the general usefulness of religion as a cross-cultural analytical category. However, all of these scholars agree that Japanese people were active participants in the processes of defining religion in the Meiji period and were responding to domestic issues alongside foreign demands. A clear illustration of domestic agendas influencing definitions was the decision to exclude select aspects of Shrine Shinto (神社神道Jinja Shintō) from the category of religion, so that they could be put to use serving the emergent 'National Science' ideology of the Meiji state (Josephson 2012:94-97). 
Hoshino (2012) presents a parallel argument with regard to how the term religion and shükyo have been redefined in the discipline of religious studies within Japan. He argues that the concept of religion has been reassessed and repurposed by Japanese scholars to the extent that it is now employed as a concept that is intentionally divorced from historical associations with Protestant Christianity. Accordingly, Hoshino argues that rather than abandoning the concept as critical scholars recommend (Fitzgerald 2004; Horii 2018; Isomae 2012), the alterations to how the category is employed make it a useful cross cultural term for scholars who seek to examine religions without elevating one tradition over another.

There is also no overall consensus amongst scholars in regard to whether the distinction between the religious (or the sacred) and the secular is an alien concept to Japan. For instance, Kleine (2013, 2019) traces parallels with indigenous Japanese concepts as early as the Heian era (794-1185), noting distinctions made between the 'rulers law' (王法ōbō) and the 'Buddha's law' (仏法buppō). Similarly, Krämer's work $(2013,2015)$ on the Buddhist priest Shimaji Mokurai contends that indigenous Japanese concepts and traditions played a substantial role in influencing how definitions of 'religion' developed in the Meiji. Reader (2004) argues that researchers should not be beholden to historical usage: 'even if there was a monolithic nineteenth century construction of "religion" as a generic term of discourse, and even if this term was imported lock, stock and barrel as a wholly new concept into Japan...this does not mean that nowadays the terms and meanings remain the same, nor that contemporary usage is necessarily founded in an ideological discourse of colonialism'.

An important consideration when debating the topic of religion in Japan, noted by Reader (2016), is the broader political context in which these debates occur. Japan's post-war constitution explicitly stipulates a separation between state and religion and this makes discussions around what constitutes religion in Japan an enduring contemporary politically sensitive issue (The Japan Times 
2019). In particular, contemporary Japanese nationalists have sought to employ academic claims that Japan has no indigenous religious traditions to justify reinstating state support of Shinto institutions arguing that it is "not [a] religion but [a] cultural manifestation of Japanese identity and an organising principle around which Japan should be built' (Reader 2016: 215). This mirrors an approach adopted by nationalists in the Meiji era (Josephson 2012:94-97). We do not argue that scholars should adjust their views due to this context but that it is important to state positions carefully and where necessary to address their wider implications.

\section{Definitions of Religion in CSR}

Critical scholars of religion are correct that in much of the academic work on religion there are pervasive implicit associations made with the monotheistic traditions, Christianity in particular. Yet, as Reader (2016: 212) and others have argued, it is important not to overlook the progress made in contemporary scholarship, which include efforts by Japanese scholars to liberate religion and shukyō from automatic Abrahamic connotations.

We recognize such developments as paralleling efforts made within the field of the cognitive science of religion (CSR) that seek to utilize definitions of religion that are applicable cross-culturally and avoid reifying Abrahamic religious models. To be certain, some scholars in the CSR field share the critical theorists' skepticism of the usefulness of the term 'religion' (Bloch 2008, 2014; Boyer 2011), but overall there is a broad consensus (Franek 2015) that the term can be useful when approached with due awareness of their limitations and clearly specified definitions (Jong 2015).

Slingerland and Bulbulia (2011: 315) suggest that religion can productively be defined as 'systems of belief and practice that revolve around commitments to supernatural, anthropomorphic beings ("gods")'. This definitional approach follows in the footsteps of earlier scholars, such as Tylor (1871) and Spiro $(1965,1971)$, who stressed the significance of supernatural agents in religion. 
Reviewing CSR definitions of religion, Franek (2015: 7) argues that an emphasis on 'counter intuitive agents' is fundamental and 'virtually unanimous in the CSR'. Applying such a definition lends support to Rappaport's famous declaration that 'No society known to anthropology or history is devoid of what reasonable observers would agree is religion' (1991: 1; see also Purzycki and Sosis 2019). Buddhism is occasionally cited as an atheistic counterpoint to this view (Durkheim 1965; Southwold 1978), but in practice Buddhist traditions are replete with counterintuitive beings arranged in vast cosmologies and various rituals directed at them (Lopez Jr 1998, 2001, 2015; Pyysiäinen 2003, 2009).

Broader definitions have also been proposed which describe religion as a 'framework of ultimately, non-verifiable metaphysical claims' that crucially does 'not necessarily involve[e] explicit theism' (Slingerland and Bulbulia 2011:315). This formulation has the advantage that it acknowledges adherence to a specific doctrine or religious institution as a non-essential component of religion, however it still maintains the view that religion is primarily about metaphysical claims and beliefs. CSR definitions of religion collectively are formulated to be inclusive of a diverse array of beliefs but there is an argument that for many practitioners across the world religion is much more about practices than endorsement of a given set of beliefs or theological propositions (McCutcheon 1997; McGuire 2008; Pals 2006; Reader and Tanabe 1998). Fortunately, this has not gone entirely overlooked and there is a substantial body of work within CSR emphasizing the core significance of ritual practices to religions (Atran and Henrich 2010; McCauley and Lawson 2002; Whitehouse 2000, 2004).

Consequently, definitions emerging within CSR in the early twenty-first century tend to be more careful to explicitly acknowledge that 'religion encompasses both religious cognition and behaviour' and note that these are linked in a system which 'at its most basic level... is composed of ritual behaviours and the supernatural agents to which people appeal' (Purzycki, Haque, and Sosis 2014:8). This kind of definition represents an improvement upon earlier attempts because it acknowledges the synergistic 
coupling of ritualized practices and supernatural beings as the core elements of religion. As this paper argues, a purely 'theocentric' frame focusing on belief in god(s) or other supernatural beings limits the ability of researchers to properly analyze environments in which ritual practices are prioritized over specific beliefs in supernatural beings, as in Japan. Despite this encouraging development the continued popularity of definitions that do not reference religious practices suggest that belief and practice are not yet reliably treated by scholars in CSR as equally core components of religion.

\section{Orthopraxic Religion in Japan}

Broadly speaking, we contend that within the Japanese religious context there is a stronger emphasis placed on practice over belief. This corresponds to a distinction in religious studies (Bell 1997; Berling 1987) between religions and cultures that are orthodoxic and those that are orthopraxic. Orthodoxic religions are those that place 'an emphasis on belief, on the assent to propositions and on doctrinal conformity' whereas those that are orthopraxic place 'greater stress on external behaviour rather than internal belief' (Szerszynski 2002:61). In both cases, the distinction is in the degree of emphasis rather than representing a binary dichotomy. It would thus be inaccurate to imagine that in Japan there are no religious texts, authorities, or communities that emphasize the importance of endorsing specified beliefs. There is concern from religious elites about maintaining doctrinal orthodoxy but there is also substantial ambiguity and a lack of interest amongst the general population. These conflicting motivations are illustrated clearly by Covell in his ethnographic exploration of contemporary Tendai Buddhism (2005) and Horii in his interviews with Nichiren Buddhist priests (2018: 168-196).

As both Shintoism and Buddhism lack regular obligatory religious services, the majority of interactions with religious institutions in Japan occur during life-stage rituals such as infant blessings or funerals, or as part of festival celebrations (matsuri 祭) found throughout Japan (Mullins 2011; Reader and Tanabe 1998; Yanagawa, Abe, and Swyngedouw 1978). Festivals are significant tourist attractions 
serving as a means to promote the products and cultural heritage of local communities (Ashkenazi 1993; Creighton 1997; Nelson 1996a; Roemer 2010). Famous festivals in large cities can attract millions of onlookers and in small villages local festivals can be among the most important community events of the year (Kawano 2005; Nelson 1996a). During festivals, the grounds of temples and shrines and surrounding areas are often packed with vendors and temporary stalls selling childrens games, sweets, grilled meat, and drinks.

While festivals are popular events that often feature complex and dramatic ritual performances it is also normal 'for participants in a matsuri festival to be unaware of which deities are enshrined or what kind of religious meanings are attached to the festival' (Fujiwara 2019:130). This lack of concern with doctrinal religious details inevitably raises questions concerning whether it is appropriate to treat festivals as religious events or if they might alternatively be better classified as simply cultural events.

However, in both Japan and China it is ritual participation rather than assent to specific religious doctrine that characterizes the majority of religious activity (Kavanagh 2016; Reader 1990, 1994; Reader and Tanabe 1998; Watson 1993). There is also a level of ambivalence amongst the public concerning the appropriate role in society of religious specialists and religious institutions. For instance, the moral authority of Buddhist priests in Japan, who often inherit their positions and can amass substantial wealth, is regularly questioned. Hence, there is a well-known pejorative phrase, 'Funerary Buddhism' (sōshiki Bukkyō葬式仏教), which implies that Buddhism in Japan is degenerate and focused on profiteering from funerals (Tamamuro 1963).

Moreover, even if we ignore that there is no reason to assume that personal belief is a fundamental and cross-cultural feature of religion, there is also no coherent approach to completely distinguish culture and religion. Religions across the globe contribute to culture not just through their devotees and priests but through their cosmologies and symbols, their histories, their influence on 
institutions, and their teachings. In Japan festivals are usually performed on the grounds of shrines and temples and are organized by priests and affiliated volunteers. They typically involve religious symbols, chants, and devotional prayers, and regardless of whether it is widely known there usually is a religious function attached, such as providing purifications or blessings to the community. To dismiss these elements as irrelevant and categorize festivals as secular cultural celebrations is difficult to justify, especially when there exist a sub-category of festivals that are more overtly secular in nature, such as the Yosakoi Soran dance festivals in which teams of dancers compete using choreographed dances.

Yanagawa and colleagues (Yanagawa 1991; Yanagawa et al. 1978) proposed that part of the reason scholars have difficulty recognizing religion in Japan is due to there being no equivalent dominance of a 'church-type institution comparable to the Catholic Church of Europe at any time in Japanese history' (Yanagawa et al. 1978:6). This historical context meant that the common religion of Japanese people was not derived from specific beliefs in God or in a strong sense of affiliation with an institution. Rather Yanagawa (1991) describes Japan as having a 'religion of human relationships' (ningen kankei no shūkyō 人間関係の宗教) based around participation in rituals and festivals that are orientated toward different groups of people, including ancestors. Another Japanese scholar, Ama (1996, 2005), similarly argues for a distinction between 'revealed' religions (sōshō shūkyō 創唱宗教), which have founders, doctrines and institutional membership, and 'natural' religion (shizen shūkyō 自然宗教), which represents the non-denominational religion of the majority of Japanese people. Ama argued that for the majority of Japanese being ‘without religion’ (mushūkyo 無宗教) refers to not believing in any single religion rather than being non-religious. Echoing this point Reader discussed the presence of a civil religion in Japan that 'is part of a wider shared arena that cuts across the boundaries of any one religious tradition... but which has points in common with them all' (Reader 1994:18). 
Developing this argument further Reader and Tanabe (1998) suggested that the core component uniting all the Japanese religious traditions into a common religion is a 'practical' orientation focused on attaining 'this-worldly' benefits (genze riyaku 現世利益). This refers to a wide array of possible benefits including protection from misfortune, recovery from illness, and success in business/relationships that are earned primarily through the performance of devotional activities. Activities including visiting shrines and temples, purchasing amulets or charms, reciting prayers, and participating in festivals. The existence of religious practices focused on healing, luck, or the provision of other benefits are common to many other religious systems, but Reader and Tanabe argue that what distinguishes these practices in Japan is their centrality; they are not peripheral but are 'at the heart of this common religion' (Reader and Tanabe 1998:31). They are endorsed not just by the laity but also doctrinally and institutionally with the majority of Buddhist temples and Shinto shrines marketing the benefits they provide (Covell 2005; Hardacre 1999). Reader and Tanabe's account could be misconstrued as presenting a depersonalized spiritual marketplace, but such an interpretation overlooks the important personalized and devotional aspects of these practices such that 'petitioning for such benefits is[regarded as] a fundamental and highly ethical religious value' (Reader and Tanabe 1998:29). Relatedly, in discussing a recent boom in Japan for pilgrimage activities that involve getting special books (goshuinchō 御朱印長) stamped at temples and shrines, Horie (201묘) notes that both the practitioners and the providers at temples and shrine emphasize the relationships being formed with the Shinto kami (a term for Shinto deities) or buddhas. Accordingly, he suggests that the interaction might be better described as revolving around the provision of psychological benefits (shinri riyaku 真理利益) rather than practical benefits.

Critically examining these concepts, Fujiwara (2019,pp. 127-130) linked Yanagawa's concept of a 'religion of human relationships' to contemporary trends in Japan revolving around the venerations 
of the concept of tsunagariつながり meaning ‘connection’ or 'belonging'. ${ }^{2}$ In line with the other scholars discussed above, she stresses the importance of acknowledging different forms of religion. In particular, she notes an important distinction between the world religions and traditional religion in Japan related to the ancestors and historic household or community systems (ie-muraイエムラ). Fujiwara $\left(2019{ }_{2}\right.$ p. 146) suggests that the contemporary emphasis on 'belonging' represents 'an attempt to re-sacralize human relationships' in response to processes of urbanization and secularization. She further argues that the key distinction from earlier forms of religion in Japan is 'that people do not symbolize the relationships with supernatural beings... instead, they directly venerate tsunagari' (2019: 146). This is an important point and is supportive of our thesis that belief-centered theocentric approaches to understanding Japanese religion fail to capture important elements of the religious dynamic in Japan. To further illustrate our arguments, we now turn to examine some recently collected data on the beliefs and ritual practices reported by a thousand respondents from across Japan.

\section{Survey of Contemporary Religious Beliefs and Practices in Japan}

Having reviewed theoretical debates surrounding the topic of religion in Japan, we move on in the second half of this paper to explore how the issues raised are reflected in contemporary data from an online survey of $\mathrm{N}=1,000$ Japanese that asked about religious beliefs and practices. (see Box 1). A full presentation of this survey is beyond the scope of this paper, so instead we examine a subsection of items in order to illustrate how the orthopraxic orientation and non-exclusive features of the Japanese environment are experienced by ordinary Japanese people. The question responses reported here were a part of a larger survey that sought to identify the demographics and evaluate the quality of data collected in questionnaires from www.lancers.co.jp, a Japanese crowdsourcing platform. Lancers functions in a

\footnotetext{
${ }^{2}$ Including a recent boom in non-denominational tsunagari themed weddings and celebrations (Fujiwara 2019:128-29).
} 
similar fashion to Amazon Mechanical Turk which has become a popular platform for social science

research (Buhrmester, Kwang, and Gosling 2011; Hauser and Schwarz 2016; Necka et al. 2016). The full survey consisted of five sections: 1. Demographics, 2. Psychological Scales, 3. Economic Games, 4. Religious Beliefs \& Ritual Practices, 5. Respondents use of the Lancer platform. Here, we discuss a subset of responses to the questions included in section four.

\section{Materials and Methods}

We collected data using an online survey constructed using the Qualtrics survey software which was advertised on Lancers. The survey was presented in Japanese and was only accessible to Lancer users through the Lancers platform. To insure we collected a broad range of respondents we released the surveys on Lancers in staggered batches over a two-week period in October 2015 during morning, afternoon, and evening slots. Repeat participation was prevented through instructions to respondents and IP blocking options within the Qualtrics platform. Subsequent analyses revealed that responses were widely distributed across Japan and that responses to common psychological scales and decisions in economic games matched closely to patterns observed in other representative samples from Japan (Kavanagh, Thomson, and Yuki 2016).

\section{Sample}

From an initial sample of 1436 responses, we excluded incomplete responses $(n=324)$ and repeat/duplicate responses $(n=112)$, leaving a final sample size of $N=1000$. The final sample was comprised of $45 \%$ male and $55 \%$ female respondents, with an age range of $18-73(\mathrm{M}=35, \mathrm{SD}=9.5)$. For nationality, $99.8 \%$ of respondents identified as Japanese (two were Chinese). Ethnically, 98.5\% identified as East Asian with 0.8\% Caucasians, 0.4\% Southeast Asian and 0.3\% Others. There was representation from all the prefectures in Japan, with more responses coming from expected population 
centers (Figure 1). The survey took an average of 20 mins to complete and participants were paid approx. \$5 (500 JPY) for compensation.

\section{Figure 1.}

Location of respondents to Lancers survey

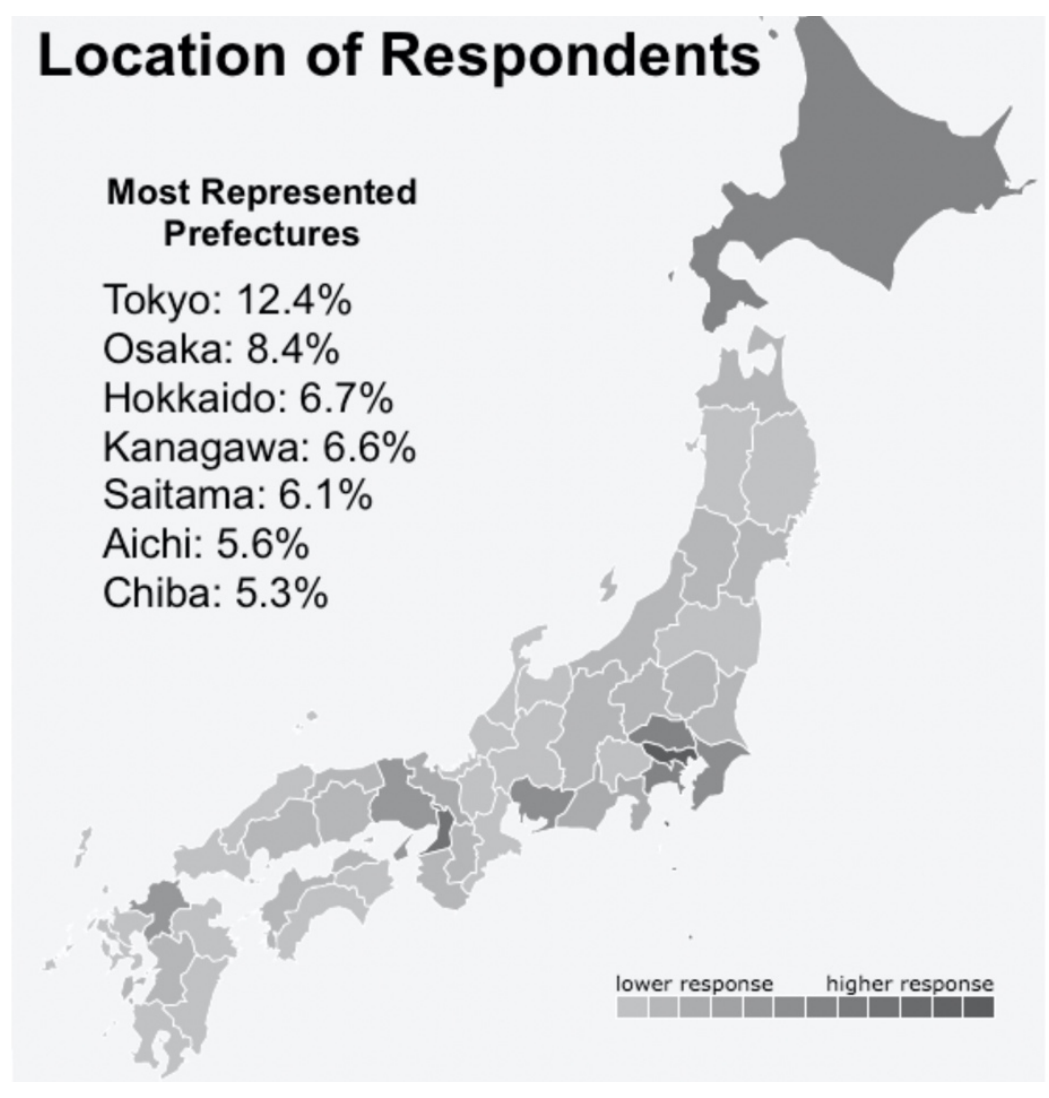

\section{Results \& Discussion}

The first group of questions in the religious belief and ritual section asked respondents whether they would say they are a religious person, independently of whether they attend religious services,

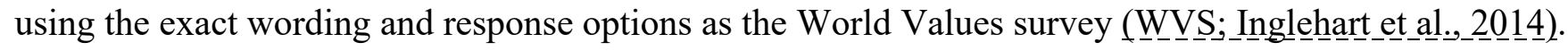
Here, we found only $10 \%$ selected religious, while $55 \%$ selected non-religious, $22 \%$ atheist, and $13 \%$ did not know. The low numbers of self-identified religious are similar to results found in other crosscultural surveys, including the Global Index of Religiosity and Atheism in which only $16 \%$ of Japanese 
respondents self-identified as 'a religious person', (WIN-Gallup International 2012), but slightly lower than the latest WVS wave in which the percentage was 21\% (Inglehart et al. 2014).

However, in the next question when we instead asked people to identify their religion from a list of options, the results were quite different: $34 \%$ identified as Buddhist, $5 \%$ as Shinto, 3\% as Christians, $45 \%$ as non-religious and $11 \%$ did not know. This suggests that many people regard themselves as possessing some form of religious affiliation but are reluctant to identify themselves as religious (Figure 2).

\section{Figure 2}

Responses to questions about religious identity
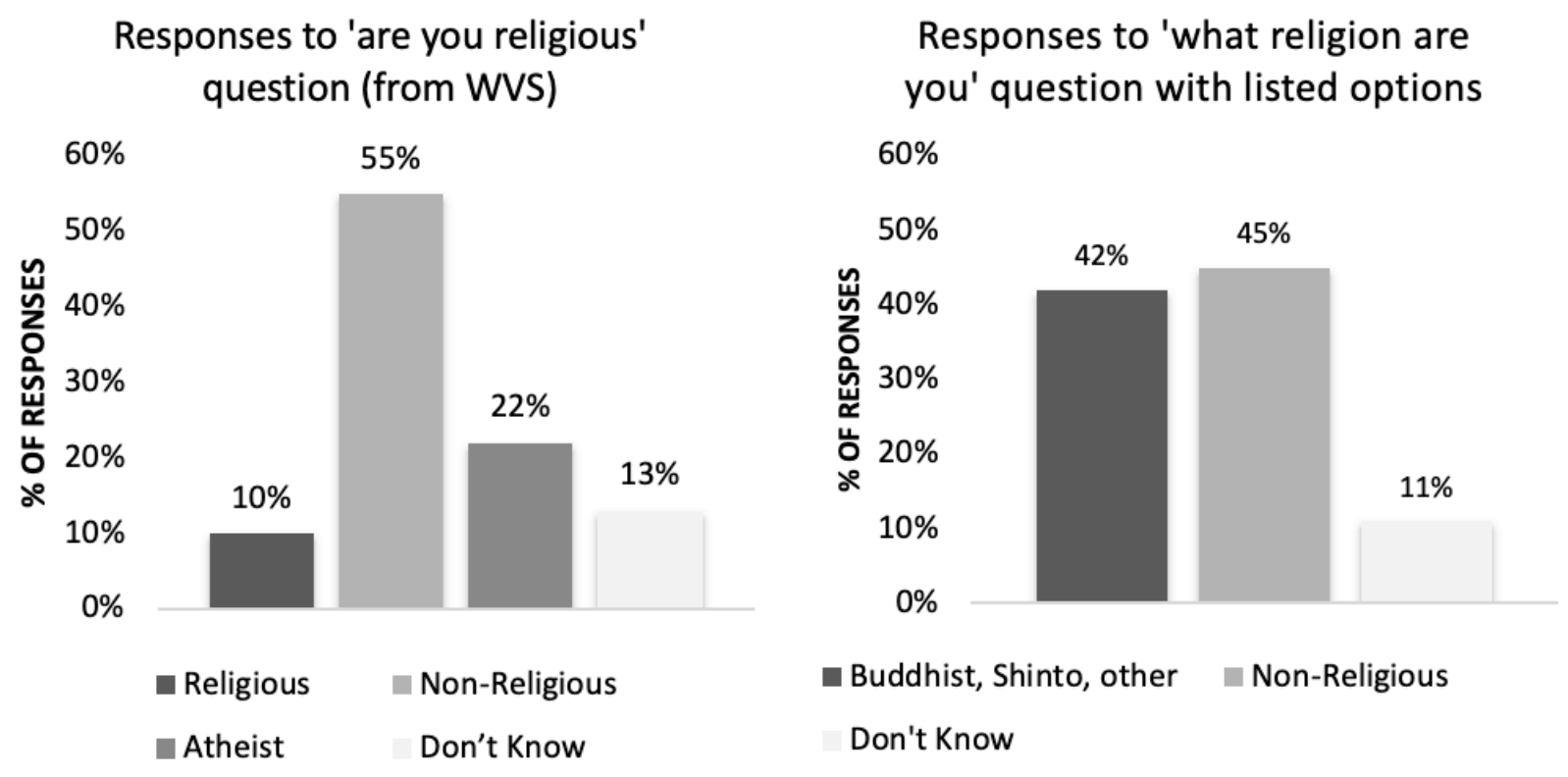

These results could be interpreted as illustrating the distinction between personal belief/selfidentity and household affiliation, however we also asked respondents more targeted questions about their endorsement of supernatural beliefs. Specifically, we used the six-item Supernatural Belief Scale (SBS; Jong \& Halberstadt 2016) which is designed for cross-cultural applications and has previously been localized in Japanese. Items ask participants how much they agree with statements such as: 'There exists an all-powerful, all-knowing spiritual being, whom we might call God', 'There is some kind of 
life after death', and 'Every human being has a spirit or soul that is separate from the physical body'. Respondents rated their agreement with each statement on a 9-point scale, ranging from -4 (strongly disagree) to 4 (strongly agree) and an average score was calculated. Figure 3 illustrates the distribution of responses, which reflected a normal distribution around the midpoint of the scale.

\section{Figure 3.}

\section{Distribution of responses to Supernatural Belief Scale.}

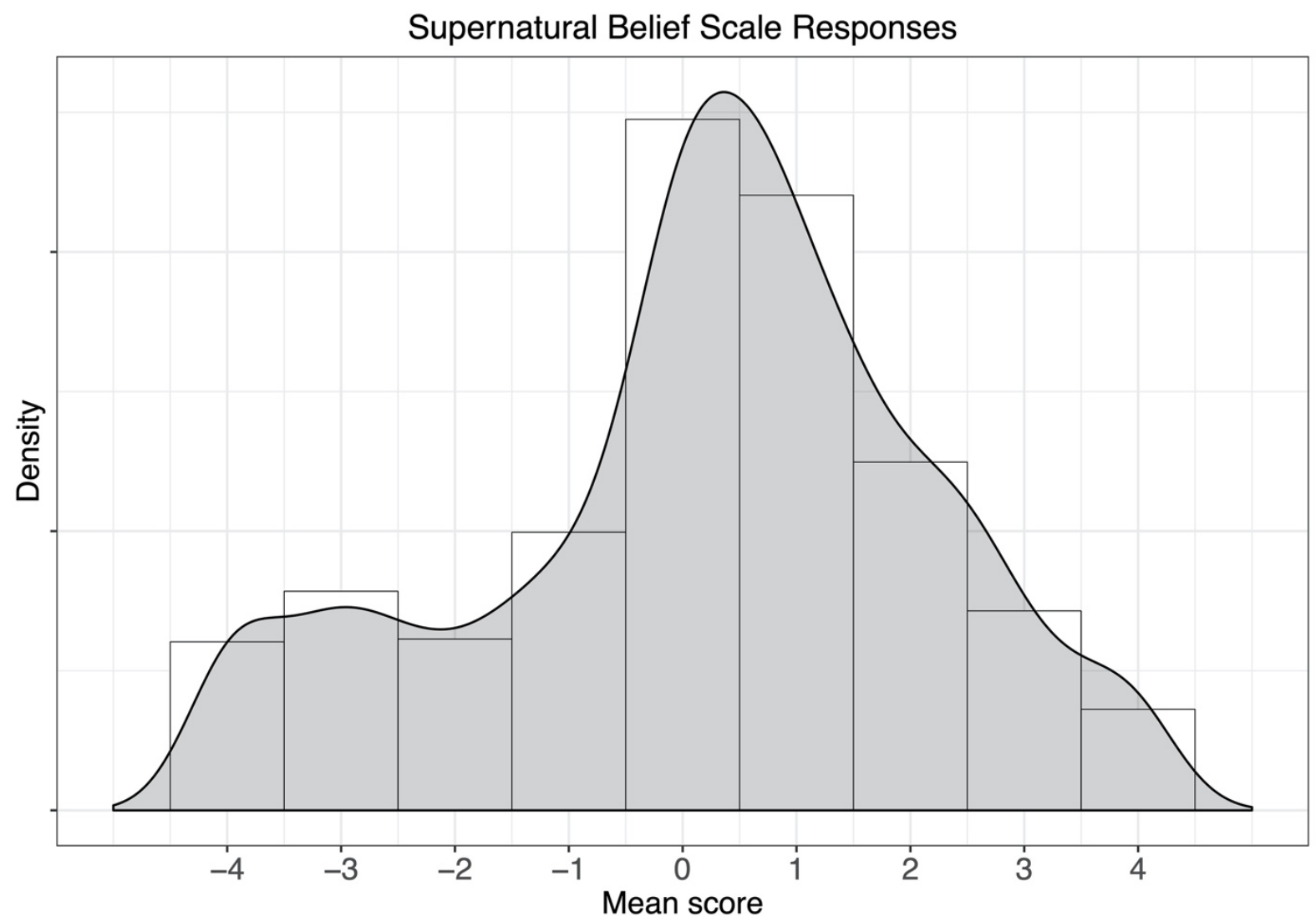

If the majority of Japanese people strongly rejected supernatural beliefs, including the existence of $\operatorname{God}(s)$, spirits, and the afterlife, we would expect the majority of scores to fall on the negative side of the spectrum, but that is not what the results show. Instead, there is a slight skew towards positive responses. It is also noteworthy that the most extreme positive and negative values were rare; with only $4.1 \%$ of respondents scoring the lowest negative mean of -4 and only $2.6 \%$ the highest positive of 4 . 
These results demonstrate that holding supernatural beliefs is not rare in Japan and that it extends well beyond the $10 \%$ of the population that self-identified as religious in response to the WVS question in our sample. This finding is also consistent with previous studies when the results are interrogated in more detail. For example, in the most recent wave of the WVS (Inglehart et al. 2014) although only 21\% of respondents self-identified as religious people, $41 \%$ of the same respondents stated that they believed in God(s). Similarly, based on their analysis of data collected in the Asian and Pacific Values Survey in 2004, Hayashi and Nikaido (2009: 174) report that although only 28\% of Japanese in the sample identified as having a religious faith, $72 \%$ reported that having a 'religious mind' was important. Hayashi and Nikaido also report that $40 \%$ felt that God, gods, or Buddha may exist. In our sample, 33\% of respondents similarly responded positively to the SBS item referring to the existence of an 'allpowerful, all-knowing spiritual being, we might call God', while $40 \%$ chose positive responses to the item referring to the existence of 'spiritual beings... such as spirits and demons'.

These findings are a clear illustration of how religious self-identification in Japan is a separate issue from whether an individual endorses various supernatural beliefs. However, a different pattern was evident amongst the self-identified Japanese atheists in our sample $(n=218)$, with only $9 \%$ offering a positive response to the SBS item concerning the existence of God and $17 \%$ endorsing the existence of 'spiritual beings'. These results run parallel to findings from research conducted in a variety of countries outside Japan examining the views of the religiously non-affiliated (Ammerman 2013; Willard and Norenzayan 2017) and the prevalence of supernatural beliefs or alternative spirituality in 'secular' societies (Glendinning 2006; Hamplová and Nešpor 2009; Josephson-Storm 2017; Lambert 2004; Tacey 2004; Voas 2008). The broad takeaway from such research is that while traditional religious affiliation and self-identification display substantial declines in secular societies, this should not be assumed as demonstrating an equivalent decrease in broader supernatural beliefs. 
While our data show that it is wrong to infer that supernatural beliefs are uncommon in Japan this does not mean that individuals regard either supernatural or religious beliefs as being very important. As we discussed in the theoretical review, in the Japanese religious environment the endorsement of specific religious beliefs and deities is not widely considered a defining feature of religious practices. The 2010-2014 WVS provides data that illustrates this point: in contrast to the United States in which $49 \%$ of respondents report that God is very important to their life, only $6 \%$ selected this option in Japan. However, this difference could be reflecting a lack of interest in a monotheistic concept of God. Responses to the next item in our survey help to clarify this issue, as we asked respondents to rate their feelings on the importance of religious belief on a 9-point scale, ranging from not at all important -4 to extremely important 4 (Figure 4).

\section{Figure 4.}

Distribution of responses to item on the importance of Religious Belief.

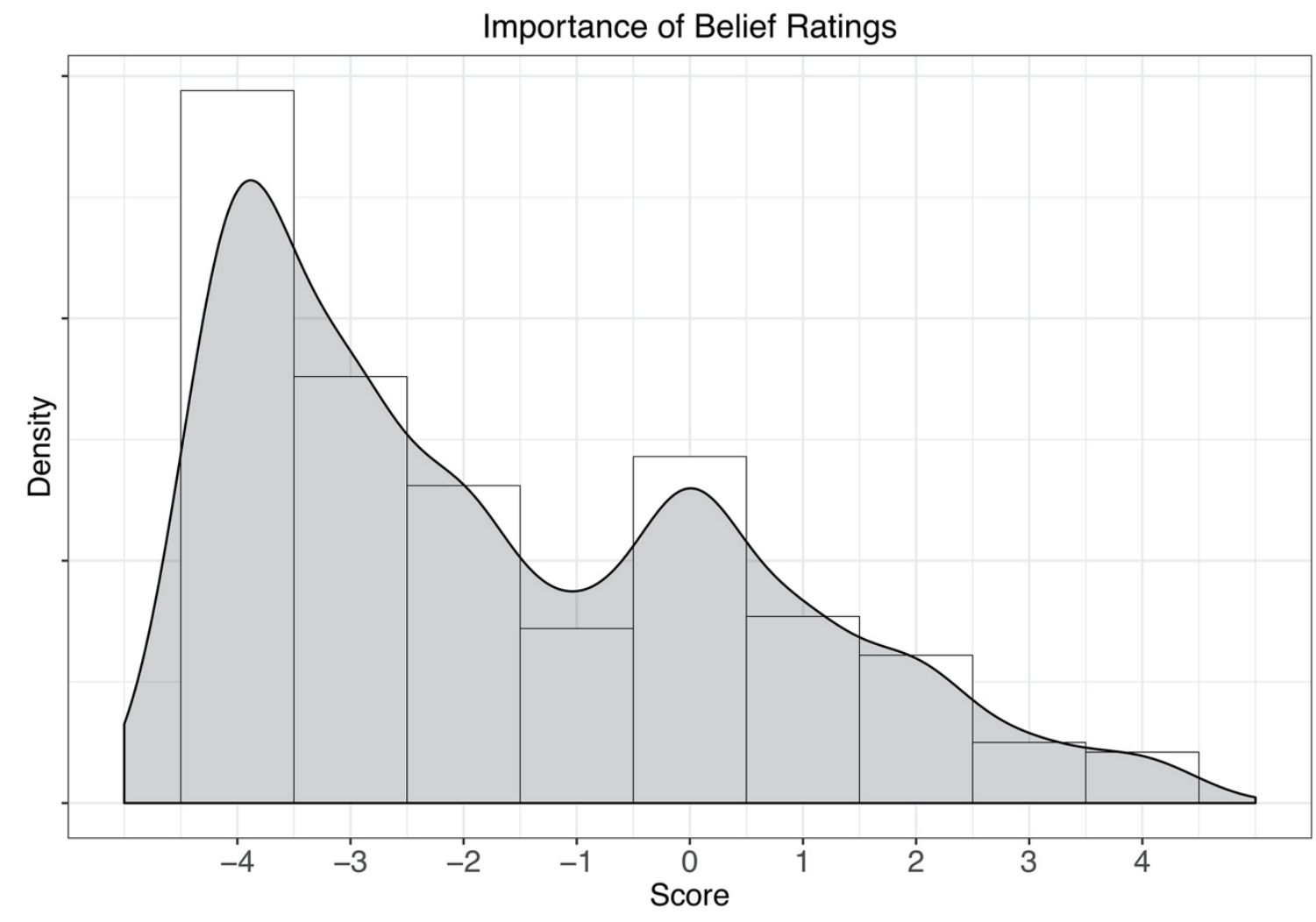


As Figure 4 illustrates, $47 \%$ of our respondents selected one of the two most extreme negative options which supports our argument about the relative lack of importance that is attributed to endorsing religious beliefs in Japan. Only $11 \%$ of respondents were in the positive end of the response scale. A separate question addressed the same topic asking respondents how important religion was in their life precisely replicating WVS wording and response options. Here again we found only $10 \%$ selecting very or rather important, while $83 \%$ of our sample selected not very important or not at all important.

Taken collectively the responses to our survey questions asking about religious selfidentification, supernatural beliefs and their relative importance demonstrate that while broad religious beliefs are not as rare as religious self-identification statistics suggest there is little evidence that many regard religious beliefs as being important. Corresponding to this we also emphasized in our theoretical review that there was wide acknowledgment amongst scholars of the greater relevance in Japanese religion to practice, including participation in festivals. Consequently, the next results we discuss relate to religious practices.

Research from the 1990 s reported that over $75 \%$ of Japanese households had Buddhist altars (Kaneko 1990:6; Okada 1994:607) but this figure has been falling with one more recent book reporting a figure of 59\% (Kawano 2005:32). This is still over half of Japanese households but it does not signify how often people are interacting with the altars or engaging in prayers more generally. To help answer this we asked respondents to indicate how often they prayed outside of 'obligatory occasions' such as funerals. In line with our expectations only $13 \%$ of our respondents reported praying once a week or more and only $5 \%$ reported praying as part of religious services. The most frequent response, accounting for $25 \%$, was that people only pray on special occasions, with $11 \%$ stating they prayed just once a year. This pattern of results was echoed in the response to questions concerning how often people visit temples, shrines, or churches. Again, only $9 \%$ indicated attending once a month or more frequently, 26\% 
reported attending only on special occasions and 19\% once a year. Complete non-attendance accounted for almost a quarter of the sample (23\%), which was similar to the amount who said they never prayed (24\%). See Figure 5 for a summary of responses to both questions.

\section{Figure 5}

Frequency of prayer and attendance at religious site

\section{Frequency of attendance at religious site and prayer}

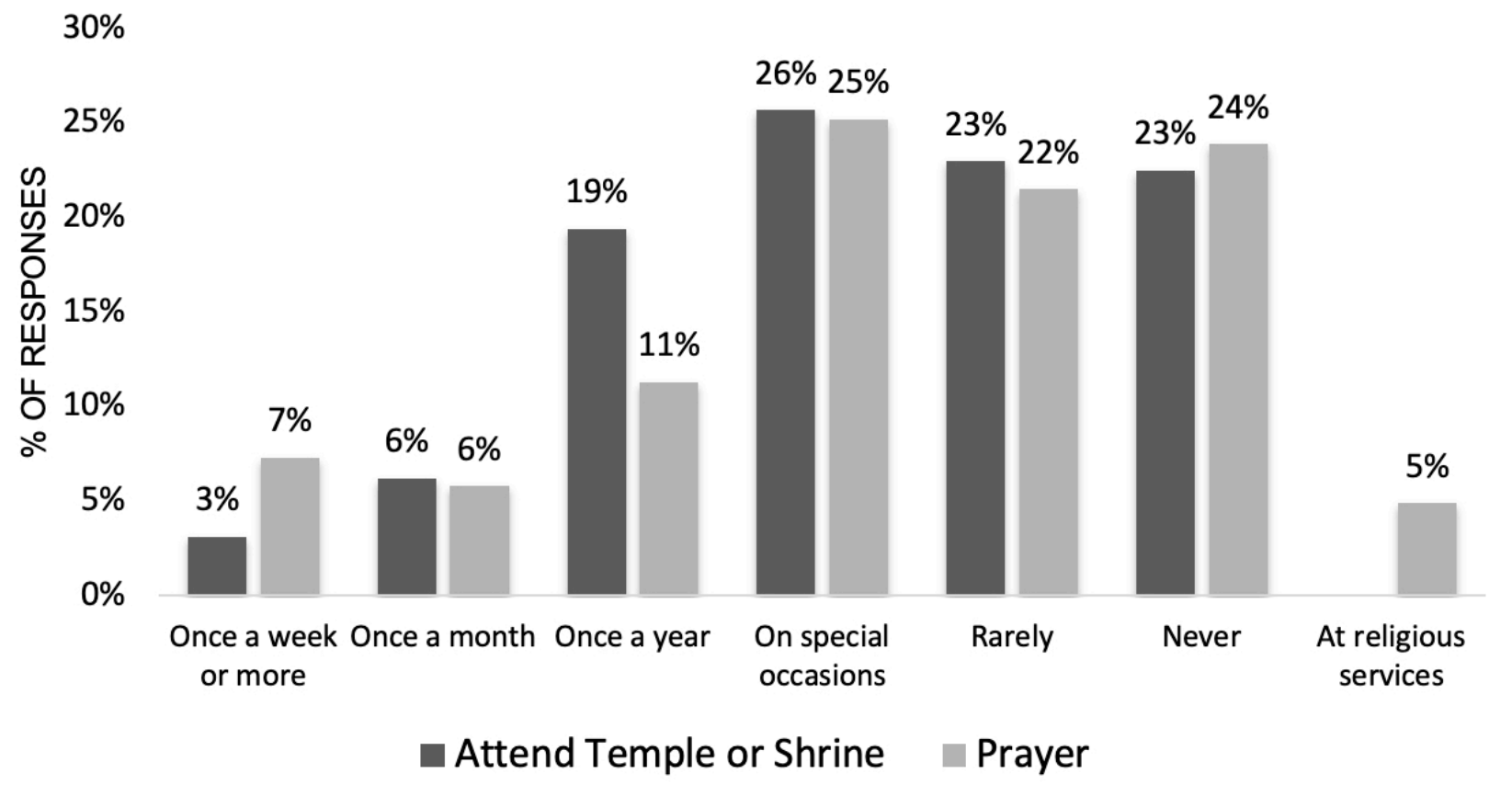

These patterns reflect that the main traditions in Japan-Buddhism and Shinto-lack requirements for regular attendance at religious services. They also illustrate the important role that festivals and other calendrical events play in the Japanese religious environment. Note that while only $10 \%$ of our sample identified as religious and 55\% as non-religious it is only $23-24 \%$ of respondents who report never attending religious sites or praying outside of obligatory events. A separate question asked specifically about respondents' festival attendance in an average year and found $66 \%$ indicated attending once or more with $34 \%$ indicating no attendance (Figure 6). 


\section{Figure 6}

Frequency of festival attendance per year

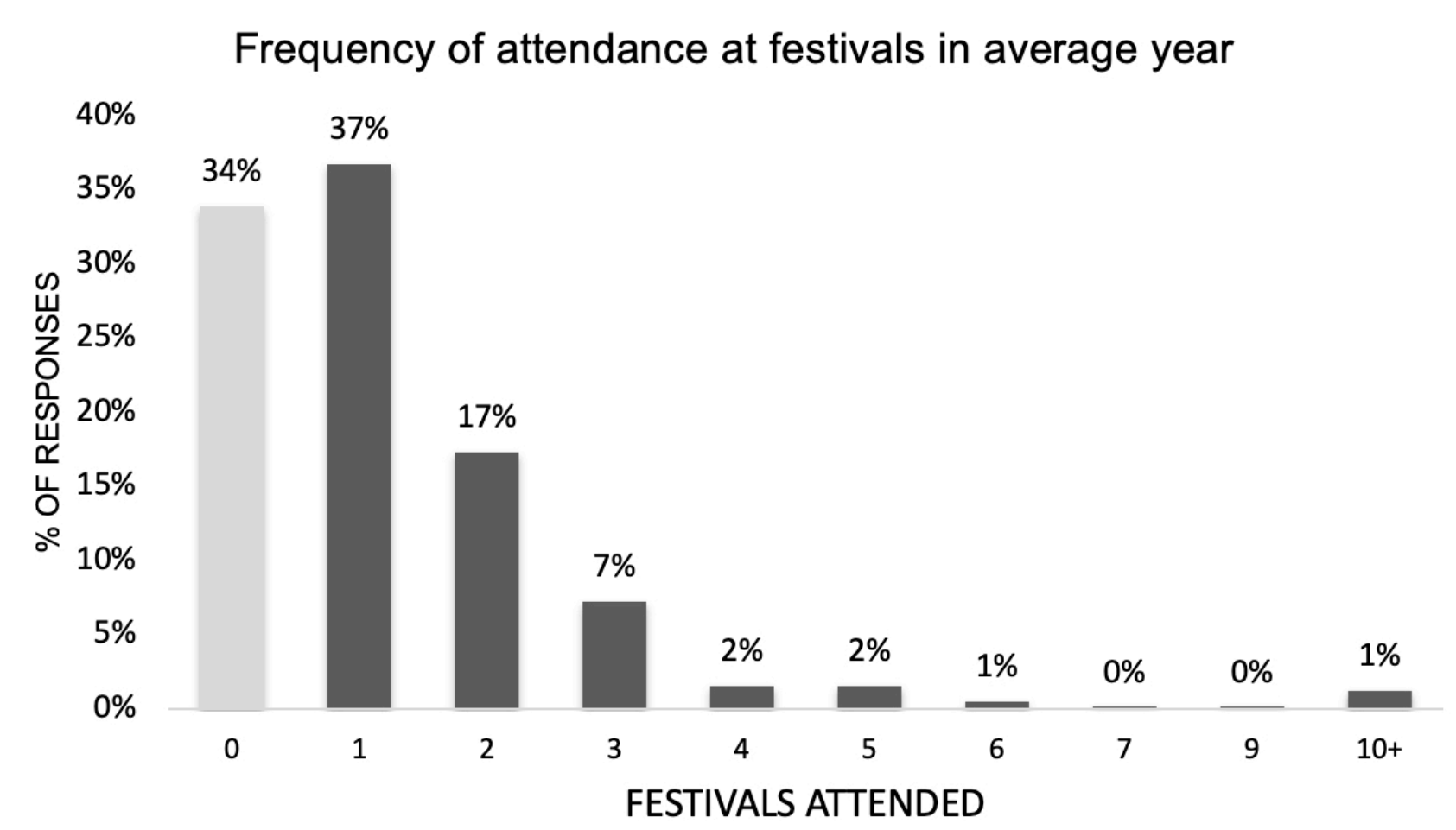

To individuals more familiar with Abrahamic traditions the lack of regular prayer and relatively infrequent attendance at religious sites may accord with that they imagine secular or non-religious patterns but we would contend that to do so implicitly places attendance at regular religious service and personal prayer as the default universal features of religion. Many scholars have adopted this stance, but we contend that there is little justification to do so when there are many religious systems that do not possess such characteristics. The error here would be akin to judging Christianity as non-religious because there is not a widespread norm of praying five times a day as there is in Islam. The infrequency of festivals may serve to make them more memorable and allow for more elaborate and arousing performances, a pattern of ritual that the cognitive anthropologist Harvey Whitehouse has labelled 'imagistic' (Whitehouse 2000, 2004) and found to be cross-culturally recurrent (Atkinson and Whitehouse 2011). 
Examining the stated motivations for attending festivals, the most strongly endorsed reasons were to participate in seasonal holiday events, sightseeing, and to pray for families and friends. Notably, few respondents explicitly endorsed statements that their attendance was motivated by religious beliefs, with $77 \%$ of responses falling below the scale midpoint. The seeking of personal benefits was also not endorsed strongly with $68 \%$ below the midpoint, but there was a more bimodal distribution in responses with $20 \%$ above the midpoint. This pattern likely reflects that the majority of respondents would have been referencing New Year or other seasonal festivals, rather than festivals attended due to specific concerns.

Nonetheless, even allowing for the usual limitations associated with asking people to self-assess their motivations (Paulhus and Vazire 2007; Van de Mortel 2008), including desirable response bias which can depress responses that indicate self-interest, it is notable that the most commonly endorsed motivations next to seasonal holiday items, were praying for family and friends and group commitments. At first glance this might seem to contradict the claims made by scholars such as Reader and Tanabe (1998) about the centrality of this worldly benefits within Japanese religion. However, the contradiction largely depends on how classifies prayers for family and friends in an intragroup collectivist social context (Kavanagh and Yuki 2013; Yuki and Takemura 2014). Furthermore, as per the arguments presented by Fujiwara (2019) and Yanagawa (Yanagawa 1991; Yanagawa et al. 1978) it may have been more instructive to focus our items on relationships (with others, groups, and deities) rather than on ‘worldly benefits' (genze riyaku 現世利益). 


\section{Figure 7.}

Endorsed motivations for attending festivals

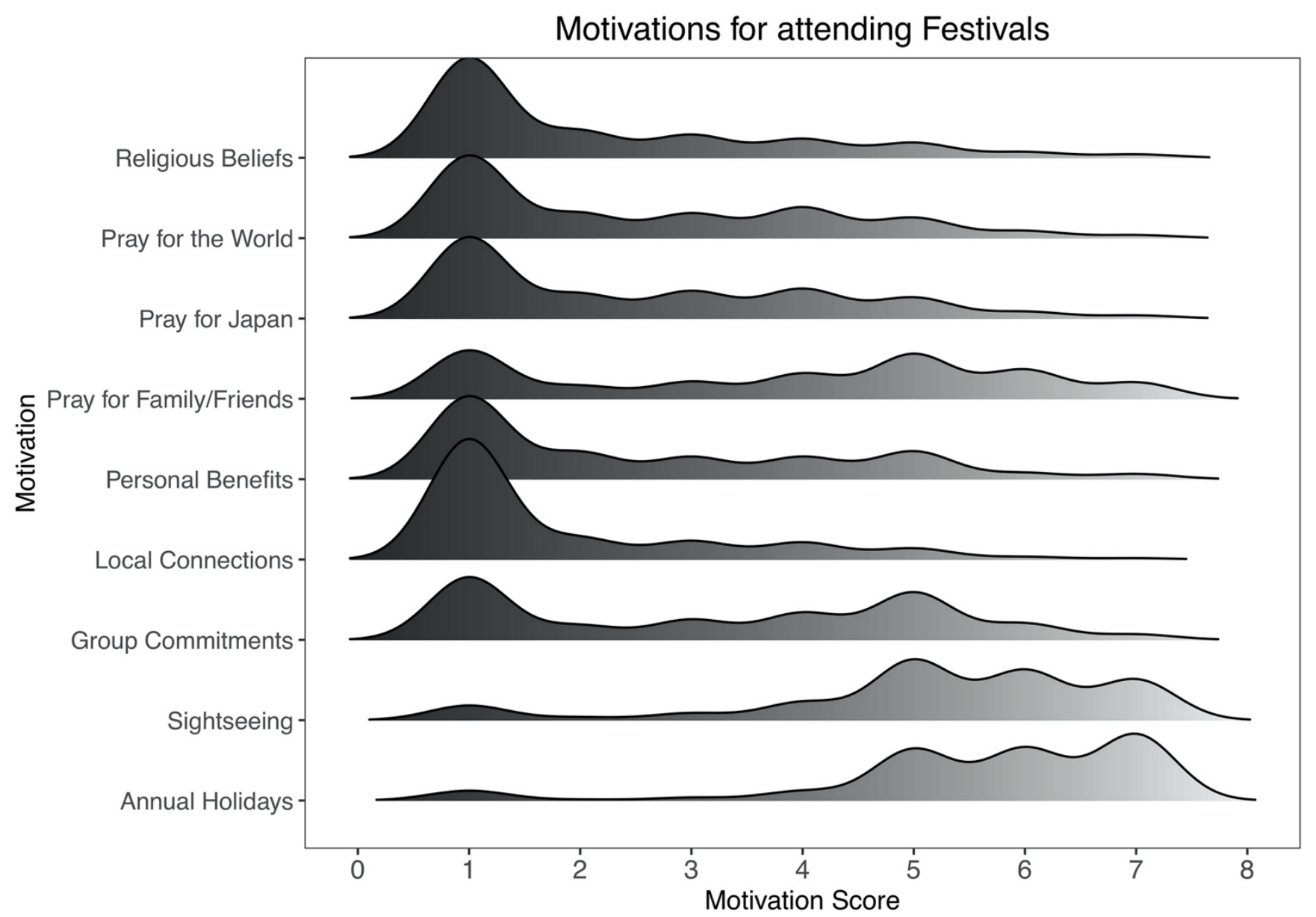

If these responses generate the impression of passive involvement in festivals it is also worth noting that $17 \%$ of our sample identified themselves as previous festival performers. In describing their performances the majority referenced dancing or performing as taiko drummers, particularly as part of annual Obon (お盆) festivities. Obon is a Japanese holiday based on a Buddhist custom to honor the spirits of the ancestors and typically involves travelling to family homes to pay respects at household graves. Another commonly mentioned role was serving as a member of a group that carries heavy wooden portable shrines (mikoshi 神與) on processions during Shinto festivals. An additional common thread in the descriptions of performances was that they were almost all celebratory in nature. This 
relates to the nature of 'performer' roles in Japanese festivals and the common characteristics of festivals which tend to be strongly community oriented. In this sense, focusing on the individual and their beliefs and motivations at festivals may be applying an inappropriately individualistic lens within a Japanese cultural environment (Markus and Kitayama 1991; Yuki 2003; Yuki and Schug 2012; Yuki and Takemura 2014).

While there are many other items that could be discussed and further conclusions that could be drawn from the survey data, the results discussed above illustrate many core features of the religious environment in Japan. In particular, this data demonstrates how religious self-identification is highly dependent on the specific wording of the question and that there is little emphasis placed on belief in particular God(s) despite not insignificant levels of supernatural beliefs. Attendance at infrequent festivals still remains a common practice and is likely to reflect the primary mode of engagement with religion in Japan outside of household rituals for honoring ancestors.

\section{Conclusion}

As we have shown there is a long-enduring debate on whether the term religion is appropriate or meaningful to describe phenomena in Japan. Based on our review of these debates and the survey evidence presented above, we argue that 'religion' may indeed be an appropriate term, albeit with important qualifications. Specifically, for the concept of religion to remain a cross-cultural category that can be applied usefully to countries like Japan it must be shorn of Abrahamic assumptions and understood to refer to a range of concepts and traditions that cluster not only around belief in supernatural beings but also in practice, such as the performance of rituals and participation in festivals, without any assumptions that these must be regular and frequent. Our call is not for scholars of religion to privilege practice over belief but rather to treat them as equally important elements when it comes to addressing religion worldwide. 
Acknowledging the various issues raised by critical scholars of religion, (Fitzgerald 2003, 2004; Horii 2016, 2018; Josephson 2012) 'religion' and ‘non-religion' remain fuzzy categories (Mandelbaum 1965). Other research has also demonstrated that it is both meaningful and productive to refer to multiple categories of religion or secularities in the Japanese context (Fujiwara 2019; Kleine 2019). However, this does not necessarily mean that efforts to utilize broader, explicitly cross cultural definitions must be abandoned (Brumann 1999). Rather, scholars should specify their definitions, outline how they serve their analytical goals, and apply them accordingly without assuming that all others will share their theoretical concerns (Jong 2015).

There is a popular literature on Japan, referred to as nihonjinron (日本人論), that presents Japan as a unique country that cannot be understood by reference to any external established theories on culture, psychology, economics, or history (Befu 1992, 2001). From the evidence provided above it could be misconstrued that we are offering our own contribution to this discourse by demonstrating how far religion in Japan deviates from common assumptions in both the popular imagination and academic research on religion. However, this is not our intention. Rather we want to emphasize that Japanese religion is not unusual unless a Western Abrahamic or theocentric frame is considered the normative standard. There are many cultures, especially across East Asia, where religious expression leans toward orthopraxic rather than orthodoxic modes (Berling 1987; Samuel 1993; Spiro 1982; Tambiah 1970; Watson 1993). Of course, we are not arguing for the replacement of theocentric conceptions of religion with an orthopraxic alternative; rather, we contend that any approach that does not properly consider the implications of orthopraxic religion will be limited in its cross-cultural generalizability. Thus, this is an issue which should be given due consideration for scholars within the CSR who seek to develop crosscultural theories of religion. 
Furthermore, in line with ongoing research into the prevalence of supernatural beliefs and alternative spirituality in secular societies, we find that while Japanese people, on average, place little emphasis on the importance of religion beliefs to their daily lives, while endorsement of supernatural beliefs demonstrated a normal distribution. This illustrates the importantance of precise wording of questions in cross-cultural research on religion and the need for further measures, like the SBS, that are intentionally designed to be generic and non-denominational. Finally, we note that the role that religion plays in Japan serves as a useful illustration that even when it is possible to identify divisions between religious and secular domains, religion is a category of human activity that it is difficult, if not impossible, to fully disentangle from other domains, such as tradition and culture. 


\section{References}

Ama, Toshimaro. 1996. Nihonjin Wa Naze Mushūkyō Na No Ka. Tokyo: Chikuma Shobō.

Ama, Toshimaro. 2005. Why Are the Japanese Non-Religious?: Japanese Spirituality: Being NonReligious in a Religious Culture. Lanham, MD: University Press of America.

Ammerman, Nancy T. 2013. 'Spiritual but Not Religious? Beyond Binary Choices in the Study of Religion'. Journal for the Scientific Study of Religion 52(2):258-78.

Ashkenazi, Michael. 1993. Matsuri: Festivals of a Japanese Town. University of Hawaii Press.

Atkinson, Quentin D., and Harvey Whitehouse. 2011. 'The Cultural Morphospace of Ritual Form: Examining Modes of Religiosity Cross-Culturally.' Evolution and Human Behavior 32(1):5062.

Atran, Scott, and Joseph Henrich. 2010. 'The Evolution of Religion: How Cognitive By-Products, Adaptive Learning Heuristics, Ritual Displays, and Group Competition Generate Deep Commitments to Prosocial Religions'. Biological Theory 5(1):18-30.

Befu, Harumi. 1992. 'Symbols of Nationalism and Nihonjinron'. Pp. 26-46 in Ideology and practice in modern Japan, edited by R. Goodman and K. Refsing. London, UK: Routledge.

Befu, Harumi. 2001. Hegemony of Homogeneity: An Anthropological Analysis of" Nihonjinron". Vol. 5. Melbourne: Trans Pacific Press.

Bell, Catherine M. 1997. Ritual: Perspectives and Dimensions. Oxford, UK: Oxford University Press.

Berling, Judith A. 1987. 'Orthopraxy'. Pp. 129-32 in The Encyclopedia of Religion. Vol. 11, edited by M. Eliade. New York, NY: Macmillan.

Bloch, Maurice. 2008. 'Why Religion Is Nothing Special but Is Central.' Philosophical Transactions of the Royal Society of London. Series B, Biological Sciences 363(1499):2055-61.

Bloch, Maurice. 2014. 'Why There Should Not Be a Cognitive Theory of "Religion"”. Presented at the 5th Meeting of the International Association for the Cognitive Science of Religion, June 20, Brno.

Boyer, Pascal. 2011. Why Would (Otherwise Intelligent) Scholars Believe in 'Religion'?

Brumann, Christoph. 1999. 'Writing for Culture: Why a Successful Concept Should Not Be Discarded'. Current Anthropology 40(S1):S1-S27.

Buhrmester, Michael D., T. Kwang, and S. D. Gosling. 2011. 'Amazon's Mechanical Turk: A New Source of Inexpensive, Yet High-Quality, Data?' Perspectives on Psychological Science 6(1):35 . 
Bullivant, Stephen, Miguel Farias, Jonathan A. Lanman, and Lois Lee. 2019. Understanding Unbelief: Atheists and Agnostics around the World. Interim Findings. Kent University.

Covell, Stephen G. 2005. Japanese Temple Buddhism: Worldliness in a Religion of Renunciation. Honolulu, HA: University of Hawai'i Press.

Creighton, Millie. 1997. 'Consuming Rural Japan: The Marketing of Tradition and Nostalgia in the Japanese Travel Industry’. Ethnology 36(3):239-54.

Durkheim, Emile. 1965. The Elementary Forms of the Religious Life. London: Free Press.

Fitzgerald, Timothy. 2003. Religion and the Secular in Japan: Problems in History, Social Anthropology and the Study of Religion. electronic journal of contemporary japanese studies.

Fitzgerald, Timothy. 2004. The Religion-Secular Dichotomy: A Response to Responses. electronic journal of contemporary japanese studies.

Franek, Juraj. 2015. 'Has the Cognitive Science of Religion (Re)Defined “Religion”?' Religio 22(1):327.

Fujiwara, Satoko. 2019. 'Practicing Belonging?: Non-Religiousness in Twenty-First Century Japan'. Journal of Religion in Japan 8(1-3):123-50.

Glendinning, Tony. 2006. 'Religious Involvement, Conventional Christian, and Unconventional Nonmaterialist Beliefs'. Journal for the Scientific Study of Religion 45(4):585-95.

Hamplová, Dana, and Zdeněk R. Nešpor. 2009. 'Invisible Religion in a "Non-Believing” Country: The Case of the Czech Republic'. Social Compass 56(4):581-97.

Hardacre, Helen. 1999. Marketing the Menacing Fetus in Japan. University of California Press.

Hauser, David J., and Norbert Schwarz. 2016. 'Attentive Turkers: MTurk Participants Perform Better on Online Attention Checks than Do Subject Pool Participants'. Behavior Research Methods 48(1):400-407.

Horie, Norichika. 2018. 'Dentō Kaiki? Soretomo Chihō Shōmetsu?”伝統 回帰? れとも地方消滅?’ Pp. 25-34 in Gendai Nihon no shūkyō jijo (現代日本の宗教事情). Tokyo: Iwanami Shoten.

Horii, Mitsutoshi. 2016. 'Critical Reflections on the Religious-Secular Dichotomy in Japan'. Pp. 260-86 in Making Religion: Theory and Practice in the Discursive Study of Religion, edited by F. Wijsen and K. von Struckrad. Leiden and Boston: Brill.

Horii, Mitsutoshi. 2018. The Category of 'Religion'in Contemporary Japan: Shūkyō and Temple Buddhism. New York, NY, US: Palgrave Macmillan.

Inglehart, Ronald, Christian Haerpfer, Alejandro Moreno, Christian Welzel, Keseniya Kizilova, Jaime Diez-Medrano, Marta Lagos, Pippa Norris, Eduard Ponarin, and Bi Puranen. 2014. 'World Values Survey: Round Six-Country-Pooled Datafile 2010-2014'. JD Systems Institute, Madrid. 
Inglehart, Ronald, and Christian Welzel. 2010. 'Changing Mass Priorities: The Link between Modernization and Democracy’. Perspectives on Politics 8(2):551-67.

Inoue, Nobutaka. 2009. 'Religious Education in Contemporary Japan'. Religion Compass 3(4):580-94.

Institute, N. H. K. Culture Research, and NHK Culture Research Institute. 2008. 2008 NHK Survey of Religion in Japan- “宗教的なもの”にひかれる日本人〜ISSP 国際比較調査（宗教）から $\sim$.

Isomae, Jun'ichi. 2012. Shūkyō Gainen Arui Wa Shūkyōgaku No Shi (The Death of the Concept of Religion and of Religious Studies). Tokyo: Tōkyō Daigaku Shuppankai.

Japan Statistics Bureau. 2019. Japan Statistical Yearbook 2019. Ministry of Internal Affairs.

Johnson, Ian. 2017. The Souls of China: The Return of Religion After Mao. First Edition edition. New York: Pantheon.

Jong, Jonathan. 2015. 'On (Not) Defining (Non)Religion'. Science, Religion \& Culture 2(3):15-24.

Jong, Jonathan, and Jamin Halberstadt. 2016. Death Anxiety and Religious Belief: An Existential Psychology of Religion. Bloomsbury Publishing.

Josephson, Jason Ānanda. 2012. The Invention of Religion in Japan. Chicago: University of Chicago Press.

Josephson-Storm, Jason Ānanda. 2017. The Myth of Disenchantment: Magic, Modernity, and the Birth of the Human Sciences. Chicago: University of Chicago Press.

Kaneko, Satoru. 1990. 'Dimensions of Religiosity among Believers in Japanese Folk Religion'. Journal for the Scientific Study of Religion 29(1):1-18.

Kavanagh, Christopher M. 2016. 'Religion without Belief'. Aeon Magazine.

Kavanagh, Christopher M., Robert Thomson, and Masaki Yuki. 2016. 'A Critical Survey of Online Users of a Popular Japanese Crowdsourcing Website.’ Nagoya, Japan.

Kavanagh, Christopher M., and Masaki Yuki. 2013. 'Culture and Group Processes' edited by M. Yuki and M. Brewer. Online Readings in Psychology and Culture 5(4).

Kawano, Satsuki. 2005. Ritual Practice in Modern Japan: Ordering Place, People, and Action. Honolulu: University of Hawaii Press.

Kleine, Christoph. 2019. 'Formations of Secularity in Ancient Japan?: On Cultural Encounters, Critical Junctures, and Path-Dependent Processes'. Journal of Religion in Japan 8(1-3):9-45.

Krämer, Hans Martin. 2013. 'How "Religion” Came to Be Translated as Shūkyō: Shimaji Mokurai and the Appropriation of Religion in Early Meiji Japan’. Japan Review 25:89-111. 
Krämer, Hans Martin. 2015. Shimaji Mokurai and the Reconception of Religion and the Secular in Modern Japan. Honolulu, HA: University of Hawai'i Press.

Lambert, Yves. 2004. 'A Turning Point in Religious Evolution in Europe'. Journal of Contemporary Religion 19(1):29-45.

Lopez Jr, Donald S. 1998. Prisoners of Shangri-La: Tibetan Buddhism and the West. Vol. 42. University of Chicago Press.

Lopez Jr, Donald S. 2001. Buddhism: An Introduction and Guide. London: Penguin UK.

Lopez Jr, Donald S. 2015. Buddhism in Practice: Abridged Edition. Princeton, NJ: Princeton University Press.

Mandelbaum, Maurice. 1965. 'Family Resemblances and Generalization Concerning the Arts'. American Philosophical Quarterly 2(3):219-28.

Markus, Hazel Rose, and Shinobu Kitayama. 1991. 'Culture and the Self: Implications for Cognition, Emotion, and Motivation.’ Psychological Review 98(2):224-253.

Maxey, Trent Elliott. 2014. The" Greatest Problem": Religion and State Formation in Meiji Japan. Cambridge, MA: Harvard University Asia Center.

McCauley, Robert N., and E. Thomas Lawson. 2002. Bringing Ritual to Mind: Psychological Foundations of Cultural Forms. Cambridge: Cambridge University Press.

McCutcheon, Russell T. 1997a. Manufacturing Religion: The Discourse on Sui Generis Religion and the Politics of Nostalgia. Oxford, UK: Oxford University Press.

McGuire, Meredith B. 2008. Lived Religion: Faith and Practice in Everyday Life. Oxford, Uk: Oxford University Press.

Metraux, A. 1995. 'Religious Terrorism in Japan: The Fatal Appeal of Aum Shinrikyo'. Asian Survey 35(12):1140-1154.

Mullins, Mark R. 2011. 'Religion in Contemporary Japanese Lives'. Pp. 63-74 in Routledge Handbook of Japanese Culture and Society. Routledge, Oxford, edited by V. Bestor, T. C. Bestor, and A. Yamagata. New York, NY: Routledge.

Necka, Elizabeth A., Stephanie Cacioppo, Greg J. Norman, and John T. Cacioppo. 2016. 'Measuring the Prevalence of Problematic Respondent Behaviors among MTurk, Campus, and Community Participants'. PLOS ONE 11(6):e0157732.

Nelson, John K. 1996a. A Year in the Life of a Shinto Shrine. Seattle, WA: University of Washington Press.

Nelson, John K. 1996b. 'Freedom of Expression: The Very Modern Practice of Visiting a Shinto Shrine'. Japanese Journal of Religious Studies 23(1):117-153. 
Okada, Shigekiyo, ed. 1994. Nihon Shukyo He No Shikaku [Approaches to Japanese Religion.]. Osaka, Japan: Toho Shuppan.

Pals, Daniel L. 2006. Eight Theories of Religion. New York: University of Oxford Press.

Paulhus, Delroy L., and Simine Vazire. 2007. 'The Self-Report Method'. Handbook of Research Methods in Personality Psychology 1:224-39.

Purzycki, Benjamin Grant, Omar Sultan Haque, and Richard Sosis. 2014.Pp. 74-91 in Extending Evolutionary Accounts of Religion beyond the Mind: Religions as Adaptive Systems, edited by F. Watts and L. P. Turner. Oxford, UK: Oxford University Press.

Pyysiäinen, Ilkka. 2003. 'Buddhism, Religion and the Concept of "God"'. Numen International Review For The History Of Religions 50(2):147-171.

Pyysiäinen, Ilkka. 2009. Supernatural Agents: Why We Believe in Souls, Gods, and Buddhas. Oxford, UK: Oxford Univeristy Press.

Reader, Ian. 1990. Religion in Contemporary Japan. Basingstoke: MacMillan.

Reader, Ian. 1994. 'Civil Religion in Contemporary Japan'. The Copenhagen Journal of Asian Studies 9(1):6.

Reader, Ian. 1996. A Poisonous Cocktail?: Aum Shinrikyo’s Path to Violence. NIAS Press.

Reader, Ian. 2000. Religious Violence in Contemporary Japan: The Case of Aum Shinrikyō. University of Hawaii Press.

Reader, Ian, and George J. Tanabe. 1998. Practically Religious: Worldly Benefits and the Common Religion of Japan. Honolulu: University of Hawaii Press.

Roemer, Michael K. 2010. 'Shinto Festival Involvement and Sense of Self in Contemporary Japan'. Pp. 491-512 in Japan Forum. Vol. 22. Taylor \& Francis.

Rowe, Mark Michael. 2011. Bonds of the Dead: Temples, Burial, and the Transformation of Contemporary Japanese Buddhism. University of Chicago Press.

Samuel, Geoffrey. 1993. Civilized Shamans: Buddhism in Tibetan Societies. Washington: Smithsonian Institution Press.

Slingerland, Edward, and Joseph A. Bulbulia. 2011. 'Evolutionary Science and the Study of Religion.' Religion 41(3):307-28.

Smith, Oliver. 2018. 'Mapped: The World's Most (and Least) Religious Countries'. The Telegraph, January 14.

Southwold, Martin. 1978. 'Buddhism and the Definition of Religion'. Man 13(3):362-79. 
Spiro, Melford E. 1982. Buddhism and Society: A Great Tradition and Its Burmese Vicissitudes. London: University of California Press.

Staufenberg, Jess. 2016. 'The Six Countries in the World That Believe in God the Least'. The Independent, March 23.

Szerszynski, Bronislaw. 2002. 'Ecological Rites: Ritual Action in Environmental Protest Events'. Theory, Culture \& Society 19(3):51-69.

Tacey, David. 2004. The Spirituality Revolution: The Emergence of Contemporary Spirituality. Routledge.

Tamamuro, Taijō. 1963. Sõshiki Bukkyō 葬式仏教 [Funeral Buddhism]. Tokyo: Daihōrinkaku.

Tambiah, Stanley Jeyaraja. 1970. Buddhism and the Spirit Cults in Northeast Thailand. Cambridge: Cambridge University Press.

The Japan Times. 2019. 'Controversy over Separation of State and Religion in Japan Rekindled after Shinto Imperial Rite'. The Japan Times Online, May 1.

Tsuji, Yohko. 2002. 'Death Policies in Japan: The State, the Family, and the Individual'. Pp. 177-99 in Family and social policy in Japan: Anthropological approaches, edited by R. Goodman. Cambridge, UK: Cambridge University Press.

Van de Mortel, Thea F. 2008. 'Faking It: Social Desirability Response Bias in Self-Report Research'. Australian Journal of Advanced Nursing, The 25(4):40.

Voas, David. 2008. 'The Rise and Fall of Fuzzy Fidelity in Europe'. European Sociological Review 25(2):155-68.

Watson, James L. 1993. 'Rites or Beliefs? The Construction of a Unified Culture in Late Imperial China'. Pp. 80-103 in China's Quest for National Identity, edited by L. Dittmer and S. S. Kim. Ithaca, N.Y.: Cornell University Press.

Whitehouse, Harvey. 2000. Arguments and Icons: Divergent Modes of Religiosity. Oxford, UK: Oxford University Press.

Whitehouse, Harvey. 2004. Modes of Religiosity: A Cognitive Theory of Religious Transmission. Walnut Creek, CA: AltaMira Press.

Willard, Aiyana K., and Ara Norenzayan. 2017. "'Spiritual but Not Religious": Cognition, Schizotypy, and Conversion in Alternative Beliefs'. Cognition 165:137-46.

WinGallup. 2014. End of Year Survey 2014- Japan. Zurich: WinGallup International.

WIN-Gallup International. 2012. Global Index of Religiosity and Atheism. WIN-Gallup International.

Yanagawa Kei’ichi. 1991. Gendai nihonjin no shūkyō (現代日本人の宗教). Kyoto: Hozokan. 
Yanagawa, Kei'ichi, Yoshiya Abe, and Jan Swyngedouw. 1978. 'Some Observations on the Sociology of Religion in Japan'. Japanese Journal of Religious Studies 5(1):5-36.

Yang, Fenggang. 2011. Religion in China: Survival and Revival under Communist Rule. Oxford University Press.

Yuki, Masaki. 2003. 'Intergroup Comparison Versus Intragroup Relationships : A Cross-Cultural Examination of Social Identity Theory in North American and East Asian Cultural Contexts.' Social Psychology Quarterly 66(2):166-183.

Yuki, Masaki, and Joanna Schug. 2012. 'Relational Mobility: A Socioecological Approach to Personal Relationships.' Pp. 137-51 in Decade of Behavior 2000-2010. Relationship Science: Integrating Evolutionary, Neuroscience, and Sociocultural Approaches, edited by O. Gillath, G. Adams, and Kunkel, A. Washington, DC: American Psychological Association.

Yuki, Masaki, and Kosuke Takemura. 2014. 'Intergroup Comparison and Intragroup Relationships: Group Processes in the Cultures of Individualism and Collectivism.' Pp. 38-65 in Culture and Group Processes, edited by M. Yuki and M. Brewer. Oxford, UK: Oxford University Press. 